\title{
WDR5 Gene
}

National Cancer Institute

\section{Source}

National Cancer Institute. WDR5 Gene. NCI Thesaurus. Code C132134.

This gene plays a role in the regulation of histone modification. 